\title{
SKRINING FITOKIMIA DAN KANDUNGAN TOTAL FLAVANOID PADA BUAH Carica pubescens Lenne \& K. Koch DI KAWASAN BROMO, CANGAR, DAN DATARAN TINGGI DIENG
}

\author{
Eko Budi Minarno
}

Jurusan Biologi Fakultas Saintek, Universitas Islam Negeri Maulana Malik Ibrahim Malang Email: budi_minarno@yahoo.com

\begin{abstract}
ABSTRAK
Carica pubescens Lenne \& K. Koch is one of the species in the tropics, which adapt to the plateau environment and low temperatures. In Indonesia, this plant is found at Cangar, Bromo, and Dieng Plateau. This study aims to determine the results of phytochemical screening and total flavonoids in fruit samples were taken from the third place. Qualitative and quantitative tests carried out in the Laboratory of Department of Biology and Chemistry, Faculty of Science and Technology, Maulana Malik Ibrahim State Islamic University, Malang. Analysis of total flavonoids using a spectrophotometer at $\lambda=510 \mathrm{~nm}$. The results of qualitative phytochemical screening tests on samples of $C$. pubescens fruits at Cangar, Bromo, and Dieng Plateau shows that the positive sample contains flavonoids, polyphenols, tannins, and triterpenoids. Quantitative test results show that the $C$. pubescens at Cangar contains total flavonoids quercetin equivalent with value $800 \mathrm{mg} / \mathrm{L}$, Bromo with value $816.65 \mathrm{mg} / \mathrm{L}$, and Dieng Plateau with value $633.35 \mathrm{mg} / \mathrm{L}$, respectively. Keywords: Carica pubescens Lenne \& K. Koch, flavonoids, phytochemicals, spectrophotometers, Bromo, Cangar, Dieng Plateau
\end{abstract}

\section{PENDAHULUAN}

Carica pubescens Lenne \& K. Koch merupakan salah satu tanaman khas dataran tinggi di Indonesia dengan kandungan vitamin C tinggi yang berpotensi sebagai bahan alami dalam penyembuhan mukosa mulut. Di Indonesia, spesies ini biasa dikenal dengan sebutan "karika", dapat dijumpai di kawasan Bromo dan Cangar Jawa Timur, serta Dataran Tinggi Dieng, Jawa Tengah. Spesies ini merupakan anggota familia Caricaceae, sehingga memiliki kelompok Genus yang sama dengan pepaya (Carica papaya) dan nampak memiliki kemiripan yang tinggi secara morfologi. Berbeda dengan pepaya, tanaman ini tumbuh di tempat dengan ketinggian 1.400-2400 meter di atas permukaan laut (dpl), temperatur rendah, dan curah hujan tinggi sehingga penduduk setempat sering menyebut pula dengan sebutan pepaya gunung. Morfologi buah C. pubescens ditunjukkan pada Gambar 1.

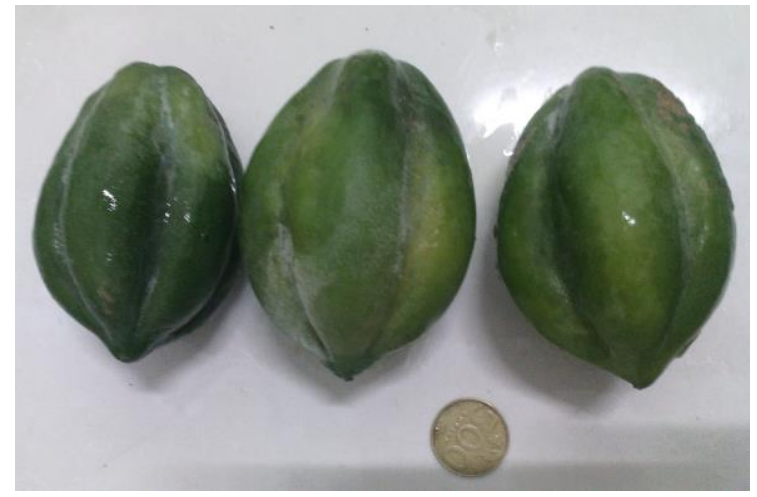

Gambar 1. Morfologi buah C. pubescens

Studi mengenai tanaman obat dan potensinya untuk kesehatan dewasa ini banyak dikembangkan, tidak terkecuali penelitian pada tanaman C. pubescens. Buah dari tanaman ini telah diteliti kandungannya sebagai zat antioksidan dan sumber flavanoid. Flavonoid adalah senyawa yang terdiri dari 15 atom karbon yang umumnya tersebar di dunia tumbuhan. Flavonoid tersebar luas di tanaman mempunyai banyak fungsi. Flavonoid adalah pigmen tanaman untuk memproduksi warna bunga merah atau biru pigmentasi kuning pada kelopak yang digunakan untuk menarik hewan penyerbuk. Flavonoid hampir terdapat pada 
semua bagian tumbuhan termasuk buah, akar, daun dan kulit luar batang (Lumbessy, 2013).

Sebagai tanaman yang berpotensi obat, buah $C$. pubescens memiliki potensi dalam proses penyembuhan luka. Luka merupakan gangguan kontinuitas suatu jaringan sehingga terjadi pemisahan jaringan yang semula normal. Luka dapat disebabkan oleh trauma yang ditimbulkan dari gangguan emosional yang hebat dan tindakan-tindakan fisik. Salah satu contoh trauma adalah trauma mekanik, yang penyebabnya antara laun prosedur perawatan dental, kecelakaan, atau tergigit sendiri sering terjadi pada mukosa rongga mulut. Trauma atau luka ditandai dengan peradangan dan kerusakan jaringan mukosa mulut. Proses penyembuhan luka dengan penambahan zat bioaktif dari buah C. pubescens diperlukan untuk perbaikan jaringan yang rusak.

Kuersetin adalah senyawa kelompok flavonol terbesar, kuersetin dan glikosidanya berada dalam jumlah sekitar $60-75 \%$ dari flavonoid. Kuersetin dipercaya dapat melindungi tubuh dari beberapa jenis penyakit degenerative dengan cara mencegah terjadinya proses peroksidasi lemak. Kuersetin memperlihatkan kemampuan mencegah proses oksidasi dari Low Density Lipoproteins (LDL) dengan cara menangkap radikal bebas dan menghelat ion logam transisi. Para ilmuwan telah melakukan penelitian untuk mengidentifikasi dan mengetahui jumlah kandungan flavonoid dari berbagai jenis makanan. Konsentrasi tertinggi dari flavonol ditemukan dalam sayuran seperti pada bawang dan brokoli, dalam buah seperti apel, ceri, beri, dan pada minuman seperti anggur merah (Waji dan Sugrani, 2012)

$C$. pubescens mempunyai banyak manfaat dalam kehidupan sehari-hari. Hasil penelitian Simirgiotis (2009) menunjukkan teridentifikasinya 19 senyawa fenol pada buah yang tumbuh di Chili. Buah tanaman ini mengandung zat antioksidan yang mampu menangkal bahaya radikal bebas dan mengandung enzim pencernaan yang meningkatkan kerja alat pencernaan, absorbsi nutrien, mengurangi stress pencernaan, menjaga $\mathrm{pH}$, menjaga kesehatan usus serta menyeimbangkan enzim-enzim alami tubuh (Rock, 2009). C. pubescens kaya akan vitamin $\mathrm{C}$, serat, dan enzim papain sebagaimana terdapat pada $C$. papaya, membantu pencernaan, bermanfaat untuk lambung dan usus besar (Hochman, 2007).
Menurut Hayati (2010), metabolit sekunder adalah senyawa hasil biogenesis dari metabolit primer. Umumnya dihasilkan oleh tumbuhan tingkat tinggi, yang bukan merupakan senyawa penentu kelangsungan hidup secara langsung, tetapi lebih sebagai hasil mekanisme pertahanan diri organisme. Kandungan senyawa metabolit sekunder telah terbukti bekerja sebagai derivate antikanker, antibakteri dan antioksidan, antara lain adalah golongan alkaloid, tanin, golongan polifenol dan turunanya. Menurut Robinson (1991) alasan lain melakukan fitokimia adalah untuk menentukan ciri senyawa aktif penyebab efek racun atau efek yang bermanfaat, yang ditunjukan oleh ekstrak tumbuhan kasar bila diuji dengan sistem biologis. Pemanfaatan prosedur fitokimia telah mempunyai peranan yang mapan dalam semua cabang ilmu tumbuhan. Meskipun cara ini penting dalam semua telaah kimia dan biokimia juga telah dimanfaatkan dalam kajian biologis.

Sejalan dengan hal tersebut, menurut Moelyono (1996) analisis fitokimia merupakan bagian dari ilmu farmakognosi yang mempelajari metode atau cara analisis kandungan kimia yang terdapat dalam tumbuhan atau hewan secara keseluruhan atau bagianbagiannya, termasuk cara isolasi atau pemisahannya. Pada tahun terakhir ini fitokimia atau kimia tumbuhan telah berkembang menjadi satu disiplin ilmu tersendiri, berada diantara kimia organik bahan alam dan biokimia tumbuhan, serta berkaitan dengan keduanya. Bidang perhatiannya adalah aneka ragam senyawa organik yang dibentuk dan ditimbun oleh tumbuhan, yaitu mengenai struktur kimianya, biosintesisnya, perubahan serta metabolismenya, penyebarannya secara ilmiah dan fungsi biologisnya (Harborne, 1984).

Skrining fitokimia merupakan cara untuk mengidentifikasi bioaktif yang belum tampak melalui suatu tes atau pemeriksaan yang dapat dengan cepat memisahkan antara bahan alam yang memiliki kandungan fitokimia tertentu dengan bahan alam yang tidak memiliki kandungan fitokimia tertentu. Skrining fitokimia merupakan tahap pendahuluan dalam suatu penelitian fitokimia yang bertujuan untuk memberikan gambaran tentang golongan senyawa yang terkandung dalam tanaman yang sedang diteliti. Metode skrining fitokimia dilakukan dengan melihat reaksi pengujian warna dengan menggunakan suatu pereaksi warna. Hal penting yang berperan penting dalam skrining fitokimia adalah pemilihan pelarut dan 
metode ekstraksi (Kristianti dkk., 2008). Skrining fitokimia serbuk simplisia dan sampel dalam bentuk basah meliputi pemeriksaan kandungan senyawa alkaloida, flavonoida, terpenoida/ steroida, tanin dan saponin menurut prosedur yang telah dilakukan oleh Harbone (Harbone, 1987) dan Depkes (Depkes, 1995).

Menurut Harborne (1984) senyawa metabolit sekunder yang umum terdapat pada tanaman adalah : alkaloid, flavanoid, steroid, saponin, terpenoid dan tannin.

a. Alkaloid

Alkaloid adalah suatu golongan senyawa yang tersebar luas hampir pada semua jenis tumbuhan. Semua alkaloid mengandung paling sedikit satu atom nitrogen yang biasanya bersifat basa dan membentuk cincin heterosiklik (Harborne, 1984). Alkaloid dapat ditemukan pada biji, daun, ranting dan kulit kayu dari tumbuh-tumbuhan. Kadar alkaloid dari tumbuhan dapat mencapai 10-15\%. Alkaloid kebanyakan bersifat racun, tetapi ada pula yang sangat berguna dalam pengobatan. Alkaloid merupakan senyawa tanpa warna, sering kali bersifat optik aktif, kebanyakan berbentuk kristal tetapi hanya sedikit yang berupa cairan (misalnya nikotin) pada suhu kamar (Sabirin, et al., 1994).

Suatu cara mengklasifikasi alkaloid adalah didasarkan pada jenis cincin heterosiklik nitrogen yang terikat. Menurut klasifikasi ini alkaloid dibedakan menjadi ; pirolidin (1), piperidin (2), isoquinolin (3), quinolin (4) dan indol (5). Alkaloid pada umumnya berbentuk kristal yang tidak berwarna, ada juga yang berbentuk cair seperti koniina (6), nikotin (7). Alkaloid yang berwarna sangat jarang ditemukan misalnya berberina (8) berwarna kuning. Kebasaan alkaloid menyebabkan senyawa ini mudah terdekomposisi terutama oleh panas, sinar dan oksigen membentuk N-oksida. Jaringan yang masih mengandung lemak, maka dilakukan ekstraksi pendahuluan petroleum eter.

b. Tanin

Secara kimia terdapat dua jenis tanin, yaitu: (1) tanin terkondensasi atau flavolan dan (2) tanin yang terhidrolisis.

1) Tanin terkondensasi atau flavolan

Tersebar luas dalam tumbuhan angiospermae, terutama pada tumbuhantumbuhan berkayu. Nama lainnya adalah proantosianidin karena bila direaksikan dengan asam panas, beberapa ikatan karbon-karbon penghubung satuan terputus dan dibebaskanlah monomer antosianidin. Kebanyakan proantosianidin adalah prosianidin karena bila direaksikan dengan asam akan menghasilkan sianidin. Proantosianidin dapat dideteksi langsung dengan mencelupkan jaringan tumbuhan ke dalam $\mathrm{HCl} 2 \mathrm{M}$ mendidih selama setengah jam yang akan menghasilkan warna merah yang dapat diekstraksi dengan amil atau butil alkohol. Bila digunakan jaringan kering, hasil tanin agak berkurang karena terjadinya pelekatan tanin pada tempatnya didalam sel.

2) Tanin yang terhidrolisis

Terbatas pada tumbuhan berkeping dua. Terutama terdiri atas dua kelas, yang paling sederhana adalah depsida galoiglukosa. Pada senyawa ini glukosa dikelilingi oleh lima gugus ester galoil atau lebih. Jenis kedua, inti molekul berupa senyawa dimer asam galat, yaitu asam heksa hidroksidifenat yang berikatan dengan glukosa. Bila dihidrolisis menghasilkan asam angelat. Cara deteksi tanin terhidrolisis adalah dengan mengidentifikasi asam galat/asam elagat dalam ekstrak eter atau etil asetat yang dipekatkan (Harborne,1987).

c. Terpenoid

Terpenoid merupakan komponenkomponen tumbuhan yang mempunyai bau dan dapat diisolasi dari bahan nabati dengan penyulingan yang disebut minyak atsiri. Minyak atsiri yang berasal dari bunga pada awalnya dikenal dari penentuan struktur secara sederhana, yaitu dengan perbandingan atom hidrogen dan atom karbon dari senyawa terpenoid yaitu 8:5 dan dengan perbandingan tersebut dapat dikatakan bahwa senyawa tersebut adalah golongan terpenoid.

Steroid adalah terpenoid yang kerangka dasarnya terbentuk dari sistem cincin siklopentana prehidrofenantrena. Steroid merupakan golongan senyawa metabolik sekunder yang banyak dimanfaatkan sebagai obat. Hormon steroid pada umumnya diperoleh dari senyawa-senyawa steroid alam terutama dalam tumbuhan (Djamal, 1988).

Menurut Harborne (1984), saponin adalah glikosida triterpen dan sterol. Saponin merupakan senyawa aktif permukaan dan bersifat seperti sabun, serta dapat dideteksi berdasarkan kemampuannya membentuk busa yang stabil dalam air dan menghomolisis sel darah merah. Dari segi pemanfaatan, saponin sangat ekonomis sebagai bahan baku pembuatan hormon steroid, tetapi saponin kadang-kadang dapat menyebabkan keracunan pada ternak (Robinson, 1991). 
d. Minyak Atsiri

Minyak atsiri bukanlah senyawa murni akan tetapi merupakan campuran senyawa organik yang kadang kala terdiri dari lebih besar dari 25 senyawa atau komponen yang berlainan. Sebagian besar komponen minyak atsiri adalah senyawa yang hanya mengandung karbon, dan hidrogen atau karbon, hidrogen dan oksigen yang tidak bersifat aromatik yang secara umum disebut terpenoid. Minyak atsiri adalah zat berbau yang terkandung dalam tanaman. Minyak ini disebut juga minyak menguap, minyak eteris, minyak esensial karena pada suhu kamar mudah menguap. Istilah esensial dipakai karena minyak atsiri mewakili bau dari tanaman asalnya. Dalam keadaan segar dan murni, minyak atsiri umumnya tidak berwarna. Namun, pada penyimpanan lama minyak atsiri dapat teroksidasi. Untuk mencegahnya, minyak atsiri harus disimpan dalam bejana gelas yang berwarna gelap, diisi penuh, ditutup rapat, serta disimpan di tempat yang kering dan sejuk (Gunawan \& Mulyani, 2004).

Berikut penjelasan beberapa cara yang biasa ditempuh dalam skrining fitokimia. Pemeriksaan golongan flavonoid dapat dilakukan dengan uji warna yaitu fitokimia untuk menentukan keberadaan senyawa golongan flavonoid dan uji adanya senyawa polifenol. Uji keberadaan senyawa flavonoid dari dalam sampel digunakan uji Wilstatter, uji Bate-Smith, dan uji dengan $\mathrm{NaOH} 10 \%$. Sedangkan uji adanya senyawa polifenol dilakukan dengan larutan penambahan $\mathrm{FeCl} 3$ adapun uji tersebut secara lengkap sebagai berikut (Achmad, 1986., Harbone, 1987):

\section{1) Uji Wilstatter}

Isolat ditambahakan 2-4 tetes $\mathrm{HCl}$ pekat dan 2-3 potong kecil logam Mg. Perubahan warna terjadi diamati dari kuning tua menjadi orange (Achmad, 1986).

2) Uji Bate-Smith

Isolat ditambahkan $\mathrm{HCl}$ pekat lalu dipanaskan dengan waktu 15 menit di atas penangas air. Reaksi positif jika memberikan warna merah (Achmad, 1986).

3) Uji dengan $\mathrm{NaOH} 10 \%$

Isolat ditambahkan pereaksi $\mathrm{NaOH} 10 \%$ dan reaksi positif apabila terjadi perubahan warna yang spesifik (Harbone, 1987).

4) Uji Golongan Polifenol

Isolat ditambahkan larutan $\mathrm{FeCl}_{3} \quad 10 \%$ dalam akuades. Reaksi positif jika memberikan warna hijau, merah, ungu, biru, atau hitam yang kuat (Harbone, 1987).
Karakterisasi sampel daun C. pubescens yang tumbuh di Dataran Tinggi Dieng telah dilakukan, meliputi kajian ciri morfologi, aktivitas antioksidan, dan pola pita protein. Masalah yang dihadapi sekarang yaitu belum tersedianya data lengkap mengenai uji kandungan kimia berupa skrning fitokimia dan kandungan total flavanoid pada sampel buah yang tumbuh di Bromo, Cangar, dan Dataran Tinggi Dieng. Dengan demikian penelitian ini perlu untuk dilakukan.

Tujuan penelitian ini adalah untuk mengetahui hasil skrining fitokimia dan kandungan total flavanoid sampel buah $C$. pubescens yang tumbuh di Cangar, Bromo, dan Dataran Tinggi Dieng.

\section{METODE PENELITIAN}

Penelitian ini dilakukan pada bulan September sampai dengan Desember 2014. Kegiatan pengambilan sampel $C$. pubescens dilakukan di kawasan Bromo dan Cangar, Jawa Timur serta Dataran Tinggi Dieng, Jawa Tengah. Kegiatan skrining fitokimia dan uji kandungan total flavanoid dilaksanakan di Laboratorium Fisiologi Tumbuhan, Laboratorium Fisiologi Hewan, Laboratorium Pendidikan, dan Laboratorium Genetika, Jurusan Biologi serta Laboratorium Kimia Organik di Fakultas Sains dan Teknologi UIN Maulana Malik Ibrahim Malang.

Alat yang digunakan untuk pengambilan sampel buah $C$. pubescens adalah kamera, kantong plastik, pita meter, pisau, kertas label, dan alat tulis. Untuk skrining fitokimia dan uji total kandungan flavonoid, alat yang digunakan antara lain: penumbuk, oven, pipet tetes, pipet mikro, neraca elektrik, tabung reaksi, rak tabung reaksi, pengaduk kaca, spatula, cawan porselen, kertas saring, corong kaca, toples maserasi, gelas ukur, hotplate, rotary vacuum evaporator, kuvet, dan spektrofotemeter.

Bahan utama berupa sampel buah $C$. pubescens Lenne \& K. Koch. Bahan untuk uji kandungan total flavonoid meliputi methanol $80 \%$, nitrogen, $\mathrm{HCl}$ pekat, bubuk $\mathrm{Mg}$, kuersetin, $\mathrm{NaNO}_{2}, \mathrm{AlCl}_{3}, \mathrm{NaOH}$, aquades, $\mathrm{FeCl}_{3}$, pereaksi Mayer, pereaksi Dragendorf, asam asetat anhidrat, asam sulfat, kloroform, blue tip, dan masker.

Setelah sampel diambil dari lapangan yaitu kawasan Bromo dan Cangar, Jawa Timur serta Dataran Tinggi Dieng, Jawa Tengah, maka selanjutnya dilakukan analisis di laboratorium. a. Preparasi Sampel 
Sampel buah dicuci dan dikeringkan selama \pm 1 minggu. Proses perajangan hingga berbentuk serbuk halus dilakukan untuk memperoleh luas permukaan yang lebih besar agar proses penetrasi pelarut ke dalam bahan dapat berlangsung dengan optimal.

b. Proses Ekstraksi

Ekstraksi buah C. pubescens dilakukan pada serbuk sampel dengan cara maserasi menggunakan pelarut methanol pada suhu ruang. Hasil maserasi disaring kemudian diuapkan pelarutnya menggunakan rotary vacuum evaporator. Selanjutnya ekstrak dipekatkan dengan penambahan nitrogen dan inkubasi pada suhu $30^{\circ} \mathrm{C}$ sampai pelarut habis menguap. Ekstrak yang diperoleh tersebut menjadi stok ekstrak buah dan disimpan pada gelas ekstrak.

c. Skrining Fitokimia

1) Uji Flavanoid

Uji flavanoid pada penelitian ini dilakukan dengan dua metode sebagai berikut.

a) Uji Wilstatter

Isolat ditambahakan 2-4 tetes $\mathrm{HCl}$ pekat dan 2-3 potong kecil logam Mg. Perubahan warna terjadi diamati dari kuning tua menjadi orange (Achmad, 1986).

b) Uji Bate-Smith

Isolat ditambahkan $\mathrm{HCl}$ pekat lalu dipanaskan dengan waktu 15 menit di atas penangas air. Reaksi positif jika memberikan warna merah (Achmad, 1986).

\section{2) Uji Saponin}

Uji saponin dilakukan menurut Simes et al. (Sangi et al., 2008). Ekstrak sampel buah sebanyak 1 gram dimasukkan ke dalam tabung reaksi, kemudian ditambahkan akuades hingga seluruh sampel terendam, dididihkan selama 2-3 menit, dan selanjutnya didinginkan, kemudian dikocok kuat-kuat. Hasil positif ditunjukkan dengan terbentuknya buih yang stabil.

3) Uji Alkaloid

Uji alkaloid dilakukan dengan terlebih dahulu melarutkan 1 gram ekstrak buah ke dalam pelarutnya yaitu metanol. Selanjutny sebanyak 2 $\mathrm{ml}$ larutan tersebut diuapkan pada cawan porselen menggunakan hotplate. Residu dilarutkan dengan $5 \mathrm{ml} \mathrm{HCl} 2 \mathrm{~N}$. Larutan yang diperoleh dibagi ke dalam 3 tabung reaksi. Tabung prtama ditambah dengan 3 tetes $\mathrm{HCl}$ $2 \mathrm{~N}$, tabung kedua ditambah dengan 3 tetes pereaksi Dragendorff, sedangkan pereaksi ketiga ditambah dengan 3 tetes pereaksi Mayer. Terbentuknya endapan menunjukkan bahwa sampel tersebut mengandung alkaloid. Reaksi dengan pereaksi Dragendorff akan terbentuk endapan jingga, dengan pereaksi Mayer terbentuk kuning.

4) Uji Polifenol dan Tanin

Uji tanin dilakukan menurut Miranda (Sangi et al., 2008). Ekstrak sampel ditambah metanol sampai sampel terendam semuanya. Kemudian ditambahkan 2-3 tetes larutan $\mathrm{FeCl}_{3} 1 \%$. Hasil positif ditunjukkan dengan terbentuknya warna hitam kebiruan atau hijau.

5) Uji Minyak Atsiri

Uji minyak atsiri dilakukan dengan terlebih dahulu menyiapkan $1 \mathrm{ml}$ ekstrak yang telah dilarutkan dalam pelarutnya. Selanjutnya larutan tersebut diuapkan pada cawan poselen di atas hotplate hingga dipeoleh residu. Dari residu tersebut jika tercium bau yang khas maka positif mengandung minyak atsiri.

6) Uji Triterpenoid

Uji triterpenoid dilakukan dengan terlebih dahulu menyiapkan $2 \mathrm{ml}$ ekstrak yang telah dilarutkan dalam pelarutnya. Larutan tersebut kemudian diuapkan di dalam caan porselen. Residu dilarutkan dengan 0,5 ml kloroform dan ditambahkan 0,5 asam asetat pekat anhidrad. Asam sulfat pekat sebanyak $2 \mathrm{ml}$ ditambahkan melalui dinding tabung reaksi. Reaksi positif triterpenoid ditunjukkan dengan terbentuknya cincin kecoklatan atau violet pada perbatasan larutan.

d. Kandungan Total Flavonoid

1) Pembuatan Kurva Kalibrasi Kuersetin

Kurva standar dibuat berdasarkan metode Rohman dkk. (2006). Larutan kuersetin dalam methanol dibuat dalam konsentrasi 700, 800, 900, 1000, dan $1100 \mathrm{mg} / \mathrm{L}$. Sebanyak 0,5 ml larutan dari berbagai konsentrasi direaksikan dengan $2 \mathrm{ml}$ akuades dan 0,15 $\mathrm{ml} \mathrm{NaNo} 25 \%$ kemudian didiamkan selama 6 menit. Sebanyak $0,15 \mathrm{ml} \mathrm{AlCl} 310 \%$ ditambahkan ke dalam larutan, kemudian diencerkan hingga volume total mencapai $5 \mathrm{ml}$ dan didiamkan selama 15 menit. Pada akhirnya, absorbansi dari larutan standar diukur pada panjang gelombang $510 \mathrm{~nm}$ menggunakan spektrofotometer UV-Vis. Kurva standar diperoleh dari hubungan antara konsentrasi (mg/L) dengan absorbansi.

b. Penentuan Total Flavanoid

Terlebih dahulu dibuat larutan dari ekstrak sampel yang telah dilarutkan dengan plarutnya (methanol) sebesar $1100 \mathrm{mg} / \mathrm{L}$. Sebanyak $0,5 \mathrm{ml}$ larutan direaksikan dengan 2 $\mathrm{ml}$ akuades dan 0,15 $\mathrm{ml} \mathrm{NaNO} 25 \%$ kemudian didiamkan selama 6 menit. Sebanyak $0,15 \mathrm{ml}$ 
$\mathrm{AlCl} 3$ 10\% ditambahkan ke dalam larutan, kemudian diencerkan hingga volume total mencapai $5 \mathrm{ml}$ dan didiamkan selama 15 menit. Selanjutnya, absorbansi dari larutan ekstrak diukur pada panjang gelombang $510 \mathrm{~nm}$ menggunakan spektrofotometer UV-Vis. Penentuan kandungan total flavonoid dinyatakan sebagai ekuivalen kuersetin dalam mg/L ekstrak.

\section{HASIL DAN PEMBAHASAN}

\section{Penyiapan Ekstrak $C$. pubescens}

Pengambilan sampel buah dari tiga tempat, yakni dua tempat di Jawa Timur meliputi kawasan Bromo dan Cangar serta satu tempat di Jawa Tengah, yakni di Dataran Tinggi Dieng, Wonosobo. Studi literatur telah dilakukan untuk mendapatkan metode ekstraksi dan konsentrasi ekstrak sampel buah $C$. pubescens yang dibutuhkan dalam uji kualitatif maupun kuantitatif

Buah C. pubescens merupakan buah dengan biji terselubung pembungkus yang berlendir, disebut sarcotesta. Maka, sebelum pengeringan atau penghilangan kadar air, sampel dicuci terlebih dahulu dari pengotor, bagian biji dan sarcotesta dihilangkan selanjutnya dipotong segitiga dengan ukuran \pm 2 $\mathrm{cm}$ selanjutnya dikeringanginkan..

Proses pengeringan sampel buah $C$. pubescens dilakukan dengan menggunakan oven dengan suhu $60^{\circ} \mathrm{C}$ selama \pm 24 jam supaya zat flavanoid terlindung dari kerusakan. Sampel yang telah dikeringkan selanjutnya ditimbang untuk mengetahui berat kering. Ekstrak buah tersebut diperoleh dengan mengekstraksi senyawa aktif dari simplisia menggunakan pelarut yang sesuai, yaitu methanol pro analys. Metode yang diterapkan pada ekstraksi buah $C$. pubescens adalah metode maserasi, sesuai dengan kepentingan dalam memperoleh sari pada buah karika. Maserasi buah dilakukan dengan proses pengekstrakan simplisia pada temperatur ruangan $\left(26^{\circ} \mathrm{C}\right.$ sampai dengan $\left.28^{\circ} \mathrm{C}\right)$, sehingga zat-zat yang terkandung di dalam simplisia relatif aman. Selanjutnya ekstrak dipekatkan dengan rotary vacuum evaporator dan inkubator.

\section{Skrining Fitokimia Sampel Buah $C$ pubescens}

Analisis secara kualitatif dilakukan dengan skrining fitokimia untuk mengetahui keberadaan senyawa flavanoid, saponin, alkaloid, polifenol, minyak atsiri, dan triterpenoid serta tanin pada sampel buah buah
C. pubescens. Hasil skrining bioaktif tersaji pada Tabel 1.

Tabel 1. Hasil skrining fitokimia terhadap buah C. pubescens

\begin{tabular}{|c|c|c|}
\hline $\begin{array}{c}\text { No. Jenis Skrining } \\
\text { Fitokimia }\end{array}$ & Gambar & $\begin{array}{c}\text { Keteranga } \\
\mathrm{n}\end{array}$ \\
\hline $\begin{array}{ll}1 & \text { Flavanoid }\end{array}$ & & positif \\
\hline 2 Saponin & & negatif \\
\hline $3 \quad$ Alkaloid & & negatif \\
\hline $\begin{array}{ll}4 & \text { Polifenol } \\
& \text { dan Tanin }\end{array}$ & & positif \\
\hline $\begin{array}{ll}5 & \begin{array}{l}\text { Minyak } \\
\text { atsiri }\end{array}\end{array}$ & & negatif \\
\hline $\begin{array}{ll}6 & \text { Triterpenoid }\end{array}$ & & positif \\
\hline
\end{tabular}

a. Flavanoid

Hasil skrining fitokimia menunjukkan bahwa buah $C$. pubescens memiliki kandungan senyawa flavonoid. Dalam penelitian ini dilakukan dua uji untuk mengidentifikasi senyawa flavanoid, yaitu uji Wilstatter dan uji Bate-Smite. Reaksi positif pada uji Wilstatter ditunjukkan dengan adanya warna jingga sedangkan reaksi positif pada uji Bate-Smite ditunjukkan dengan adanya warna merah. Warna merah pada uji flavonoid dikarenakan terbentuknya garam flavilium (Achmad, 1986) menurut reaksi berikut. 


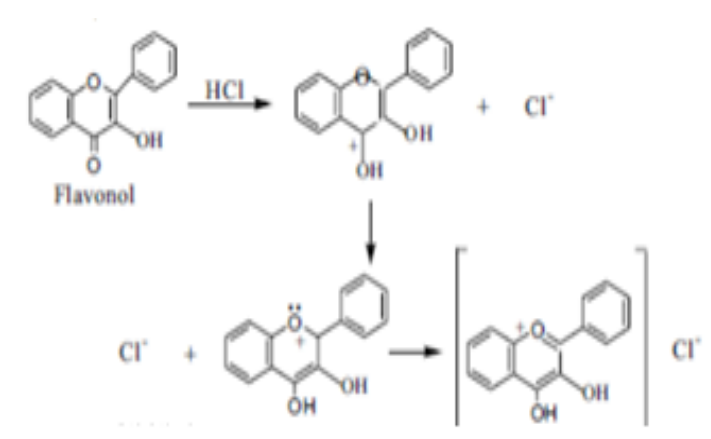

Gambar 2. Reaksi terbentuknya garam flavilum

b. Saponin

Kandungan saponin pada sampel buah C. pubescens dinyatakan negatif, yakni dengan tidak munculnya busa setelah pengocokan. Sifat yang dimiliki saponin antara lain mempunyai rasa pahit, membentuk busa yang stabil dalam larutan air. Ditinjau dari rasa buahnya, $C$. pubescens tidak memiliki rasa pahit. Jika memungkinkan terdapat sedikit saponin pada buah maka dengan proses pengeringan akan menghilangkan kandungan saponin tersebut. Menurut Robinson (1995) senyawa yang memiliki gugus polar dan nonpolar bersifat aktif permukaan sehingga saat saponin dikocok dengan air dapat membentuk misel. Pada struktur misel, gugus polar menghadap ke luar sedangkan gugus nonpolarnya menghadap ke dalam, keadaan inilah yang tampak seperti busa. Sementara itu penelitian oleh Rahmawati (2014) menyatakan saponin C. papaya ditemukan pada sampel daun.

\section{c. Alkaloid}

Berdasarkan hasil pengujian terhadap sampel buah $C$. pubescens, diketahui bahwa sampel tersebut negatif alkaloid. Ketika ditetesi dengan reagen Dragendroff dan reagen Mayer, sampel buah $C$. pubescens berubah warna menjadi jingga kecokelatan, namun tidak dihasilkan adanya endapan.

Tujuan penambahan $\mathrm{HCl}$ pada uji alkaloid pada penelitian ini karena alkaloid bersifat basa sehingga diekstrak dengan pelarut yang mengandung asam (Harborne, 1996). Pada penelitian ini kemungkinan kompleks kalium alkaloid yang terbentuk tidak sampai batas jenuh sehingga tidak mampu membentuk endapan. Pada uji positif alkaloid dengan pereaksi Mayer, diperkirakan nitrogen pada alkaloid akan bereaksi dengan ion logam $\mathrm{K}^{+}$dari kalium tetraiodomerkurat (II) membentuk kompleks kalium-alkaloid yang mengendap. Hasil positif alkaloid pada uji Dragendorff juga ditandai dengan terbentuknya endapan coklat muda sampai kuning, yaitu kalium alkaloid.

d. Polifenol dan Tanin

Berdasarkan hasil skrining fitokimia, diketahui bahwa sampel buah $C$. pubescens positif mengandung senyawa polifenol dan tanin. Hal ini dapat dilihat dari perubahan warna yang terjadi pada saat penambahan larutan $\mathrm{FeCl}_{3} 1 \%$ yaitu warna hijau kehitaman. Pada penambahan larutan $\mathrm{FeCl}_{3} \quad 1 \%$ diperkirakan larutan ini bereaksi dengan salah satu gugus hidroksil yang ada pada senyawa tanin. Pereaksi $\mathrm{FeCl}_{3}$ dipergunakan secara luas untuk mengidentifikasi senyawa fenol termasuk tanin (Robinson, 1995).

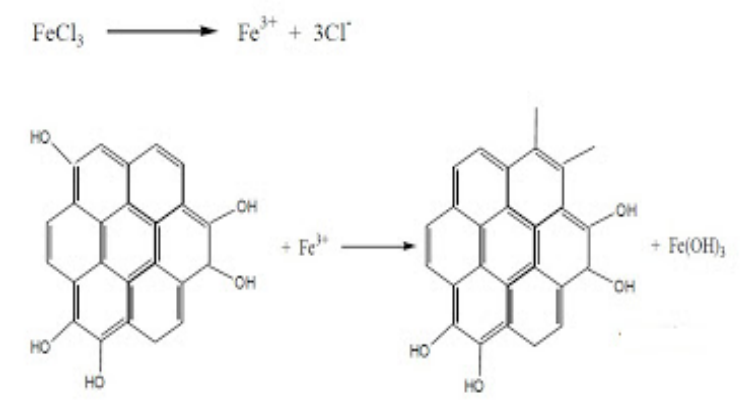

Gambar 3. Reaksi pada uji polifenol dan tanin

\section{e. Minyak Atsiri}

Sampel buah C. pubescens pada penelitian dimungkinkan tidak mengandung minyak atsiri karena tidak diperoleh residu dengan bau yang khas setelah larutan uji diuapkan pada cawan porselen. Bau yang ditimbulkan tidak tajam.

\section{f. Triterpenoid}

Hasil skrining fitokimia menunjukkan bahwa dalam sampel buah $C$. pubescens positif mengandung triterpenoid, ditandai dengan terbentuknya cincin kecoklatan pada larutan uji setelah penambahan asam sulfat pekat sebanyak $2 \mathrm{ml}$ melalui dinding tabung. Beberapa penelitian menunjukkan bahwa tanaman $C$. papaya mengandung metabolit sekunder triterpenoid menunjukkan bahwa senyawa tersebut memiliki aktivitas sebagai antibakteri yaitu monoterpenoid linalool, diterpenoid, phytol, triterpenoid saponin, triterpenoid glikosida (Marlinda, 2013).

\section{Uji Kuantitatif Sampel Buah C. pubescens}

Penentuan kadar flavanoid total diawali dengan membuat kurva standar kuersetin dengan konsentrasi 700, 800, 900, 1000, dan 1100 mg/L pada panjang gelombang $510 \mathrm{~nm}$ seperti pada 
Gambar 3. Kurva ini berguna dalam membantu menentukan kandungan flafanoid total sampel buah C. pubescens.

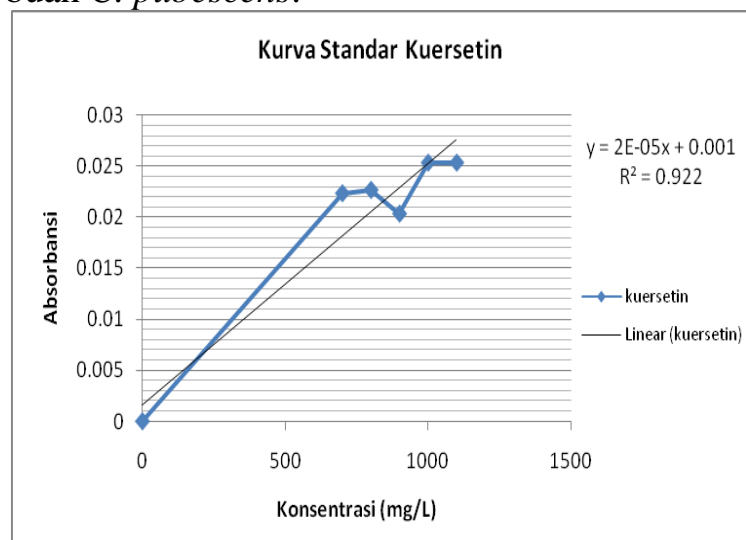

Gambar 4. Kurva standar kuersetin

Penelitian terhadap larutan standar kuersetin menghasilkan persamaan regresi $\mathrm{y}=$ $2 \mathrm{E}-05 \mathrm{x}+0,001$ dengan pengukuran linearitas sebesar 0,922. Andriyani dkk. (2008) menyatakan bahwa nilai linearitas yang mendekati satu menunjukkan persamaan regresi tersebut linear dan dapat digunakan. Dapat dikatakan bahwa absorbansi merupakan fungsi yang besarnya berbanding lurus dengan konsentrasi dan mengikuti persamaan regresi linear:

dengan:

$$
y=A x+B
$$

$\mathrm{x}$ : konsentrasi $(\mathrm{mg} / \mathrm{L})$

y: absorbansi (A)

Persamaan tersebut pada kurva kalibrasi standar kuersetin digunakan sebagai pembanding dalam analisis kuantitatif pada pengukuran kandungan flavonoid total ekstrak metanol sampel buah $C$. pubescens. Berdasarkan hasil pengukuran terhadap konsentrasi ekstrak sebesar $1100 \mathrm{mg} / \mathrm{L}$ maka diperoleh data sebagai beikut.

Tabel 2. Penentuan flavanoid total sampel buah C. pubescens pada pengambilan konsentrasi ekstrak $1100 \mathrm{mg} / \mathrm{L}$

\begin{tabular}{cclc}
\hline No. & $\begin{array}{c}\text { Asal } \\
\text { Sampe } \\
1\end{array}$ & \multicolumn{1}{c}{$\begin{array}{c}\text { Abso } \\
\text { rbansi }\end{array}$} & $\begin{array}{c}\text { Kandungan } \\
\text { flavanoid total } \\
\text { ekuivalen } \\
\text { kuersetin }(\mathrm{mg} / \mathrm{L})\end{array}$ \\
\hline 1 & Bromo & 0,017 & 800 \\
2 & Cangar & 0.01733 & 816,65 \\
& & 3 & \\
3 & Dieng, & 0.01366 & 633,35 \\
& & 7 & \\
\hline
\end{tabular}

Dari hasil tersebut dapat diketahui bahwa kandungan flavanoid total tertinggi adalah pada ekstrak sampel yang berasal dari kawasan
Cangar, Batu, Jawa Timur sebesar 816,65 mg/L ekuivalen kuersetin pada pengambilan 1100 ppm ekstrak. Hal ini dimungkinkan karena adanya perbedaan tempat tumbuh tanaman yang didukung oleh iklim dan unsur tanah. Sitompul dan Guritno (1995) menerangkan bahwa untuk dapat berkembang biak dan menyelesaikan siklus hidupnya secara lengkap, tanaman membutuhkan keadaan lingkungan tertentu, yaitu keadaan lingkungan yang dapat untuk mengekspresikan program genetiknya secara penuh. Perbedaan genetika dan lingkungan tumbuh yang optimum pada $C$. pubescens memberikan penampilan pertumbuhan yang optimum. Suatu model klasik yang sampai sekarang tetap berlaku dapat digunakan adalah penampilan tanaman (P) sebagai fungsi dari faktor genetik tanaman $(\mathrm{G})$ dan lingkungan $(\mathrm{E})$.

Sampel buah $C$. pubescens yang diambil dari kawasan Cangar berasal dari tumbuhan liar pada ketinggian \pm 1.600 meter dpl, kurang matang, dan berukuran relatif lebih kecil daripada sampel buah dari dua kawasan lainnya. Di Dataran Tinggi Dieng, tanaman C. pubescens merupakan tanaman budidaya yang ditanam pada ketinggian \pm 2000 meter dpl sehingga pertumbuhan buah optimal. Di Kawasan Bromo, sampel buah diambil pada ketinggian \pm 1.700 meter dpl dan memiliki ukuran yang relatif sama dengan sampel buah yang berasal dari Dataran Tinggi Dieng. Hasil penelitian Rohyami pada tahun 2012 menjelaskan bahwa kandungan senyawa flavanoid pada buah masak Phaleria macrocarpa rata-rata 1,7647 mg.L-1 sedangkan pada buah mentah rata-rata adalah $2,1535 \mathrm{mg}$.L1 , menunjukkan perbedaan kandungan flavanoid pada tingkat kematangan yang berbeda.

Tumbuhan dalam satu spesies yang sama, dalam hal ini $C$. pubescens teradaptasi secara berbeda-beda terhadap keadaan suhu yang menyangkut minimum, optimum, dan maksimum untuk hidupnya secara keseluruhan. Demikian untuk komponen fungsi fisiologisnya, walaupun suhu dapat berubah dengan variasi pada kondisi yang berbeda dan menurut keadaan tumbuhan. Sallisbury dan Ross (1995) menerangkan bahwa cahaya memacu sintesis flavanoid dalam beberapa sel terspesialisasi di salah satu organ. Produksi flavanoid memerlukan gula sebagai fosfoenolpiruvat dan eritrosa-4-fosfat yang menediakan beberapa atom karbon yang diperlukan bagi cincin-B flavanoid serta sebagai unit asetat untuk cincinA flavanoid. Gula, khususnya sukrosa, dapat diperoleh dari proses peruraian pati atau lemak 
di organ penyimpan saat perkembangan kecambah atau dari fotosintesis di sel yang mengandung klorofil. Cahaya juga berefek pada susunan kloroplas.

Secara umum, dapat dijelaskan bahwa lingkungan memberikan pengaruh yang signifikan terhadap kandungan kimia pada spesies $C$. pubescens jika spesies tersebut tumbuh di tempat yang berbeda meskipun kondisi lingkungan sama yakni temperatur rendah, ketinggian di antara $1.400-2.400$ meter dpl, dan berada di sekitar sumber belerang.

\section{KESIMPULAN}

Berdasarkan hasil analisis, maka diperoleh kesimpulan sebagai berikut.

1. Hasil uji kualitatif melalui skrining fitokimia terhadap sampel $C$. pubescens yang tumbuh di kawasan Cangar, Bromo, dan Dataran Tinggi Dieng menunjukkan bahwa sampel tersebut positif memiliki kandungan flavanoid, polifenol dan tanin, serta triterpenoid.

2. Hasil uji kuantitatif menunjukkan bahwa pada $C$. pubescens yang tumbuh di kawasan Cangar memiliki kandungan total flavanoid ekuivalen kuersetin sebesar $800 \mathrm{mg} / \mathrm{L}$, di Bromo sebesar 816,65 mg/ L, dan Dataran Tinggi Dieng sebesar 633,35 mg/L.

\section{UCAPAN TERIMA KASIH}

Ucapan terima kasih kami sampaikan kepada LPPM UIN Maulana Malik Ibrahim Malang yang telah mendukung dan mendanai penelitian ini.

\section{DAFTAR PUSTAKA}

Achmad, S.A. 1986. Kimia Organik Bahan Alam. Jakarta: Karnunika

Ajizah, A.2004. Sensitivitas Salmonella typhirium terhadap Ekstrak Daun Psidium guajava L.Bioscientiae. 1: p. 31-38.

Andriyani, R. Lisawati, Y. dan Maimunah, 2008. Penentuan Aktivitas Antioksidan, Kadar Fenolat Total dan Likopen pada Buah Tomat (Solanum lycopersicum L.), Jurnal Sains dan Teknologi Farmasi, 13, 3-4

Anonim. 2009. Terpenoid. http://nadjeeb.wordpress.com [10 Februari 2011]

Departemen Kesehatan RI, 1989, Materia Medika Indonesia, Jilid VI, Jakarta.
Djamal, R., 1988. Tumbuhan Sebagai Sumber Bahan Obat. Pusat Penelitian. Universitas Negeri Andalas.

Harbone, J.B., 1987, Metode Fitokimia: Penuntun Cara Modern Menganalisis Tumbuhan, Terbitan Kedua, ITB Bandung.

Harborne JB. 1987. Metode Fitokimia. Padmawinata K, Soediro I, penerjemah. Bandung : Penerbit ITB. Terjemahan dari : Phytochemical methods.

Harborne, J.B. 1987 Metode Fitokimia Penuntun cara menganalisis Tumbuhan, terjemah Padmawinat Bandung: ITB press

Harborne, J.B., 1984. Phitochemical Method. Chapman and Hall ltd. London.

Harborne, J.B., , 1987. Phitochemical Method. Chapman and Hall ltd. London.

Herbert, R.B., 1989. The Biosynthesis of Secondary Metabolism. Campman and Hall 29 West $35^{\text {th }}$ Street, New York.

Hidayat, S. 2001. Prospek Pepaya Gunung (Carica Pubescens) dari Sikunang, Pegunungan Dieng, Wonosobo. Prosiding Seminar Sehari: Menggali Potensi dan Meningkatkan Prospek Tanaman Hortikultura Menuju Ketahanan Pangan. Pusat Konservasi Tumbuhan Kebun Raya Bogor-LIPI, Bogor.

Judoamidjojo M., Darwis A.A., Gumbira E., 1990. Teknologi Fermentasi. IPB. Bogor.

Kristianti, A. N, N. S. Aminah, M. Tanjung, dan B. Kurniadi. 2008. Buku Ajar Fitokimia.Surabaya: Jurusan Kimia Laboratorium Kimia Organik FMIPA Universitas

Lumbessy,Mirna. Dkk.2013. Uji total Flavonoid pada beberapa tanaman obat tradisional diwaitina Kecamatan Mangoli Timur Kabupaten Kepulauan Sula, Maluku Timur. Jurnal MIPA UNSRAT.vol.02,No.01,Hal:50-55

Manitto, P., 1981. Biosintesis Produk Alami. Terjemahan : Koensoenmardiyah. IKIP Semarang Press. Semarang.

Markham, K.R., 1982. Cara Mengidentifikasi Falvanoid. Alih Bahasa : Kosasih Padmawinata, (1988). ITB. Bandung.

Markham, K.R., 1988, Techniques of Flavonoids Identification, diterjemahkan oleh Kosasih Padmawinata, Penerbit ITB, Bandung.

Moelyono, M.W., 1996. Panduan Praktikum Analisis Fitokimia. Laboratorium 
Farmakologi Jurusan Farmasi FMIPA. Universitas Padjadjaran. Bandung.

Mursiti, S. 2013. Isolasi, Identifikasi, Dan Elusidasi Struktur Senyawa Alkaloid Dalam Ekstrak Metanol-Asam Nitrat Dari Biji Mahoni Bebas Minyak (Swietenia macrophylla, King).Jurnal MIPA 36 (2): 169-177 (2013).

Mursiti, S. 2013. Isolasi, Identifikasi, Dan Elusidasi Struktur Senyawa Alkaloid Dalam Ekstrak Metanol-Asam Nitrat Dari Biji Mahoni Bebas Minyak (Swietenia macrophylla, King).Jurnal MIPA 36 (2): 169-177 (2013).

Natural Resources Conservation Service, 2010. Germplasm Resources Information Network (GRIN) Taxonomy for Plants. http://plants.usda.gov/java/profile? symbol=CAPU39 [15 Januari 2010].

Pusat Perlindungan Varietas Tanaman Departemen Pertanian Republik Indonesia. 2006. Panduan Pengujian Individual Kebaruan, Keunikan, Keseragaman dan Kestabilan.

Robinson, T., 1991. The Organic Constituen of HigherPlants. $6^{\text {th }}$ Edition. Department of Biochemistry. University of Massachusetts

Rock, Red. 2009. Product Review - Wild Mountain Papaya Extract. http://www. associatedcontent.com/article/1987516/pr oduct review wild mountain papaya.ht $\underline{\mathrm{ml}}$ [15 Januari 2010].

Rohman, A. Riyanto, S., dan Utari, D. 2006. Aktivitas Antioksidan, Kandungan Fenolat Total, dan Kandungan Flavanoid Total Ekstrak Etil asetat Buah Mengkudu serta Fraksi-fraksinya. Majalah Farmasi Indonesia, 17,137-138.

Rohyami, Yuli. 2008. Penentuan Kandungan Flavonoid dari Ekstrak Metanol Daging Buah Mahkota Dewa (Phaleria macrocarpa Scheff Boerl. Jurnal LOGIKA hal. 1-8 Volume 5, Nomor 1

Sabirin, M., Hardjono S., dan Respati S., 1994. Pengantar Praktikum Kimia Organik II. UGM-Yogyakarta.

Salisbury et al. 1995. Fisiologi Tumbuhan Jilid 3. Bandung: Penerbit ITB

Sangi, M.; Runtuwene, M.R.J.; Simbala, H.E.I. dan Makang, V.M.A. 2008. Analisis Fitokimia Tumbuhan Obat di Kabupaten Minahasa Utara.Chemistry Progress. Vol 1, hlm: 47-53
Sastrohamidjojo, H., 1996. Sintesis Bahan Alam. Gadjah Mada university Press. Yogyakarta.

Simirgiotis. 2009. Identification of Phenolic Compounds from The Fruits of The Mountain Papaya Vasconcellea pubescens a. dc. Grown in Chile by Liquid Chromatography-uv Detection-Mass Spectrometry. Journal Food Chemistry. 115:775-784.

Sitompul, S. M \& B. Guritno. 1995. Analisis Pertumbuhan Tanaman. Gadjah Mada University Press: Yogyakarta.

Waji, R.A. dan Sugrani, Andis. Makalah Kimia Organik Bahan Alam : Flavanoid (Quercetin). Program S2 Kimia Fakultas MIPA Universitas Hasanuddin

Wikipedia. 2011. Pepaya Gunung. http://id.wikipedia.org/wiki/index $\quad[10$ Februari 2011]. 